\title{
Correction: Early Detection of Dengue Fever Outbreaks Using a Surveillance App (Mozzify): Cross-sectional Mixed Methods Usability Study
}

Von Ralph Dane Marquez Herbuela ${ }^{1,2}$, PhD; Tomonori Karita ${ }^{3}$, PhD; Thaddeus Marzo Carvajal ${ }^{1,4}$, PhD; Howell Tsai $\mathrm{Ho}^{5}, \mathrm{PhD}$; John Michael Olea Lorena ${ }^{6}, \mathrm{PhD}$; Rachele Arce Regalado ${ }^{7}, \mathrm{MA}$; Girly Dirilo Sobrepeña ${ }^{8}$, MD; Kozo Watanabe ${ }^{1,4}, \mathrm{PhD}$

\footnotetext{
${ }^{1}$ Center for Marine Environmental Studies, Ehime University, Matsuyama, Japan

${ }^{2}$ Department of Civil and Environmental Engineering, Graduate School of Science and Engineering, Ehime University, Matsuyama, Japan

${ }^{3}$ Department of Special Needs Education, Graduate School of Education, Ehime University, Matsuyama, Japan

${ }^{4}$ Biological Control Research Unit, Center for Natural Science and Environmental Research, De La Salle University, Manila, Philippines

${ }^{5}$ College of Arts, Sciences and Education, Trinity University of Asia, Quezon City, Philippines

${ }^{6}$ St. Luke's College of Nursing, Trinity University of Asia, Quezon City, Philippines

${ }^{7}$ Guidance Counseling and Testing Department, University of Santo Tomas-Angelicum College, Quezon City, Philippines

${ }^{8}$ Pediatrics Department, Novaliches District Hospital, Quezon City, Philippines
}

\section{Corresponding Author:}

Kozo Watanabe, $\mathrm{PhD}$

Center for Marine Environmental Studies

Ehime University

3 Bunkyo-cho

Matsuyama,

Japan

Phone: 81899279847

Email: watanabe.kozo.mj@ehime-u.ac.jp

\section{Related Article:}

Correction of: https://publichealth.jmir.org/2021/3/e19034

(JMIR Public Health Surveill 2021;7(4):e29795) doi: 10.2196/29795

In "Early Detection of Dengue Fever Outbreaks Using a Surveillance App (Mozzify): Cross-sectional Mixed Methods Usability Study" (JMIR Public Health Surveill 2021;7(3):e19034) two errors were noted.

In the originally published manuscript, the footnotes of Tables 1 and 3 listed incorrect currency conversions. In Table 1, footnote "b" originally read:

$$
\text { Philippine peso }\left(\text { US } \$ 48.10=\boldsymbol{P}_{1}\right)
$$

In Table 3, footnote "d" originally read:

$$
\text { Philippine peso }\left(U S \$ 52.16=P_{1}\right)
$$

In the corrected version of the manuscript, both of these footnotes have been changed to read:

$$
\text { Philippine peso }\left(\text { US } \$ 1={ }^{P} 50.5 ; 5 \text {-year average rate }\right)
$$

The correction will appear in the online version of the paper on the JMIR Publications website on April 22, 2021, together with the publication of this correction notice. Because this was made after submission to PubMed, PubMed Central, and other full-text repositories, the corrected article has also been resubmitted to those repositories. 
This is a non-peer-reviewed article. Submitted 20.04.21; accepted 20.04.21; published 22.04.21.

Please cite as:

Herbuela VRDM, Karita T, Carvajal TM, Ho HT, Lorena JMO, Regalado RA, Sobrepeña GD, Watanabe K

Correction: Early Detection of Dengue Fever Outbreaks Using a Surveillance App (Mozzify): Cross-sectional Mixed Methods Usability Study

JMIR Public Health Surveill 2021;7(4):e29795

URL: https://publichealth.jmir.org/2021/4/e29795

doi: $10.2196 / 29795$

PMID:

(CVon Ralph Dane Marquez Herbuela, Tomonori Karita, Thaddeus Marzo Carvajal, Howell Tsai Ho, John Michael Olea Lorena, Rachele Arce Regalado, Girly Dirilo Sobrepeña, Kozo Watanabe. Originally published in JMIR Public Health and Surveillance (https://publichealth.jmir.org), 22.04.2021. This is an open-access article distributed under the terms of the Creative Commons Attribution License (https://creativecommons.org/licenses/by/4.0/), which permits unrestricted use, distribution, and reproduction in any medium, provided the original work, first published in JMIR Public Health and Surveillance, is properly cited. The complete bibliographic information, a link to the original publication on https://publichealth.jmir.org, as well as this copyright and license information must be included. 